\title{
Review of Green Buildings Spreading and Levels
}

\author{
Mohmd Sarireh $^{1 *}$ \\ 1 Department of Civil Engineering, Faculty of Engineering, Tafila Technical University, 179, 66110 Tafila, Jordan \\ e-mail:m.sarireh@gmail.com
}

\begin{abstract}
In fulfilling worldwide broad concerns about environment impacts and changes leads to global warming, green building is becoming more adopted and increasingly in owners' and occupiers' demand and provision. Source scarce and depletion imposes construction to develop sustainable green building as efficient construction innovation. The paper aims to review green building literature research in design and construction. Green building can go integrally in design, construction, and operation in sustainable operation. Green building adoption maximizes savings in energy, water for other beneficial uses, decrease waste and $\mathrm{CO}_{2}$ emission and avoiding cost of treatment, transferring, and disposal of waste. From results, it is found out that construction companies and firms should follow and practice green building standards in plans and programs for new construction and rehabilitation of existing buildings, and should keep records for data in specific centers established for this purpose. In a continuous development process, records will give clear history of experience and show financial performance and benefits considering levels of environmental sustainability and green building innovations, savings, and acceptable healthenvironmental manners.
\end{abstract}

Keywords: green, LEED, water saving, energy saving, waste stop, go green.

\section{INTRODUCTION}

The worlds of construction and design are changing rapidly as the global desire for sustainable building increases. The community is not determinant when it comes to new vision after experiencing the overwhelming effects on ecosystem change and depletion of natural resources. Current green building initiations catch the environmental concerns and sustainability and development for resources that exhausted in constructing projects including water and energy savings, waste reduction, and resource development and construction material durability and efficiency (sustainability) [1]. The green building process includes the decreasing of impacts on mankind and ecosystems, so next generations can get safe and healthy manner life despite of modernization and the new models of construction and resource depletion. The light is focused on eco-friendly materials and its impacts, and on environmental sustainable local and worldwide infrastructure [2]. According to Jordan Green Building Council [3], green building can be defined as that the building can fulfill the requirement for decreasing the negative effects and increasing positive effects on climate, health, and natural eco-system in achieving the use of resources effectively with less emissions and money saving. The definition of green building concludes that the sustainability is not only involves the construction industry but also all societal infrastructures worldwide. Changes in the construction industry practices goes in the same way for sustainability for the unstable world eco-system, and contractors and owners are not insisting on the requirements for changes in construction industry. So, green building is defined simply as the building that doesn't have bad effect on the eco-system. Ideally green building allows the client, designer, and occupant from preserving the natural environment around the project site and building during building construction and industry process in fulfilling its 
goal. Also, green building is defined as the building that can avoid successfully the harmful chemicals (off-gassing), using renewable materials, or recycled materials, purchasing local industrial materials, choosing energy effective uses, picking water saving fixtures, the usage of salvage points, and reducing job site waste to avoid landfill activities and extra cost [4]. Also, it is stated that green building could be related in the form and function of mending matches or property, updating fixtures or assets when looking to purchase or selling property, when planning a makeover the assets [5].

The construction industry has a big involvement to gross domestic product (GDP) in countries around the world. Any industry has two aspects: the excessive one that is seen often everywhere and the bad side which the construction industry fails to reduce its bad impacts on eco-system. Using up natural resources is the worst effect on the eco-system that is caused by the construction industry which consumes around $40 \%$ of natural resources in the industrialized countries. It uses nearly $70 \%$ of electric power and produces between $45 \%$ and $65 \%$ of the rubbish. Furthermore, people live indoors mostly as residents in buildings which are directly affected by health and productivity issues due to the nature of the buildings in materials, and construction process technology. As a reason for the new idea and concept of developers, owners, and consultants, green building developments are quickly becoming the new ideal specifications. And those that will not acclimate these specifications, will become supreme, and need promotion and substituting, or danger losing value. Green building design is the gate and bridge approach for future development. Green building science and art are based on architecture, technology in materials and process, and practice that include sustainable design, energy inspection, and building management. Measurements and fundamental knowledge such as total building parameters such as performance and energy check will assure moral green building design and practice [6].

Construction and design are changing obligatory as the global need for sustainable building increases. Current research aims to focus the light and attention on green building definitions, aspects, practices, and benefits through the literature of researchers and practices in construction projects worldwide.

\section{BACKGROUND}

Green building practices are growing worldwide for its incentives offered by the government, in addition to the savings in water and energy, and the adding values for the surrounding environment. But the system of construction by green technology still has the uncertainty that faces usually the investment in the field. Sustainability that is the desire and target for the green building process and materials, but what preferable more is the possible zero product bad effect on environment and human beings in order to be effective in less bad and much good impacts and effective cost for capital and maintenance operations [7].

Background section is organized into four parts including green building experience worldwide, green building rating systems, energy consumption and replenishable resources, sustainability and green buildings. And following the gathered data, and information in these subtitles are presented. Many green buildings were also created to reduce the unfavorable impacts of development on human health. While no standard definition exists, most green buildings focus on different issues, typically building orientation and site selection, energy and water consumption, materials selection, construction methodology, and life-cycle costing [8].

\section{Practices and application programs of green building}

One of the most concerns in the whole world is the availability of energy resources as the currently-used resources such as coal, natural gas, and petroleum are used up by the time [9]. For this reason, a lot of studies have been accoplished to find out the most useful ways to use the earth's resources efficiently besides saving the eco-system and economy of the world and using new sustainable resources. Maple Tree Business City, Singapore, which was designed considering the Green Mark Platinum Certification level. The project mainly consists of 2 blocks of 14 and 17 story business park buildings, and 1 block of 18 story office building. The landscape surface is proposed to cover the entire $1^{\text {st }}$ story and mezzanine vehicle park. The project is pioneering and advancing in using the condenser of waste heat from chiller for swimming pool heating which keeps the temperature of the water in the swimming pool in acceptable high temperature 
all the time instead of keeping it at the ambient temperature. The predesign stage that sets forth clear goals of owners and project and measuring these goals through the project life cycle is adopted during design and reviewing. The client, architecture, and their legislatures are included in this predesign stage to set the proposed achievable goals. Then the concept design illustrate the conceptual idea during brain storming, graphs and sketches during workshops and meetings. And stake-holders may or may not be involved depending on the size of the project and complexity of details and work volumes. A facilitator is required in this stage of the project lifespan phases to take part of discussion and issuing required proofs and guarantee the applications of laws and legislations. Then the project is motivated and stirred into the design development stage through the development of schematic design, layout and foot print of the project of volumes and shapes. Stake-holders are involved in the details for the eco sustainability, aesthetics, cost, maintainability, flexibility, approachability, functionality, and safekeeping and protection according to the requirements of eco-systems. In addition to the use of waste for heating the swimming pool, other architect's and nature's techniques were employed and used to get the benefit of sunlight as shown in Figure 1, 2, 3, 4, and 5. The effective green building key features are: building orientation massing, vegetation and native plants (less water consumption), energy effectiveness, saving applications including energy and water savings and proposed recycling operations, renewable energy, local eco-friendly building materials, and reduction of waste reduction and recycling.

One of the major consumers of global resources is the construction industry which uses
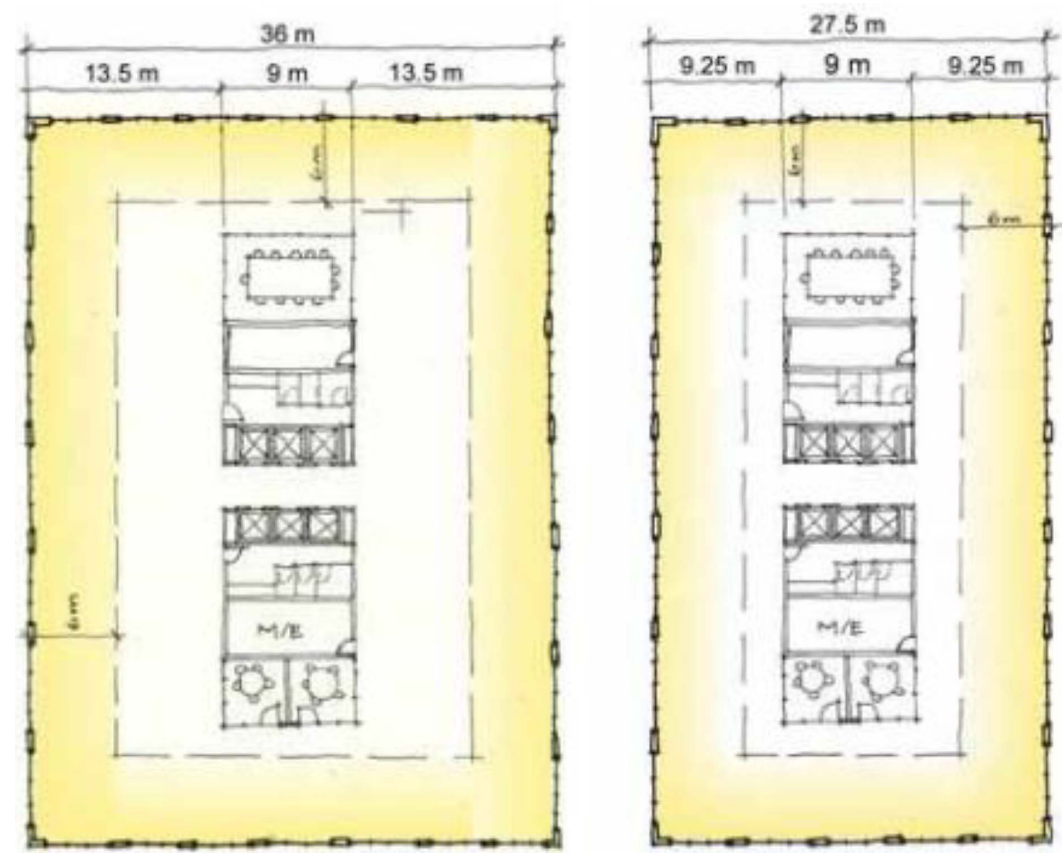

Fig. 1. Effect of floor plate on artificial lighting requirements [6]

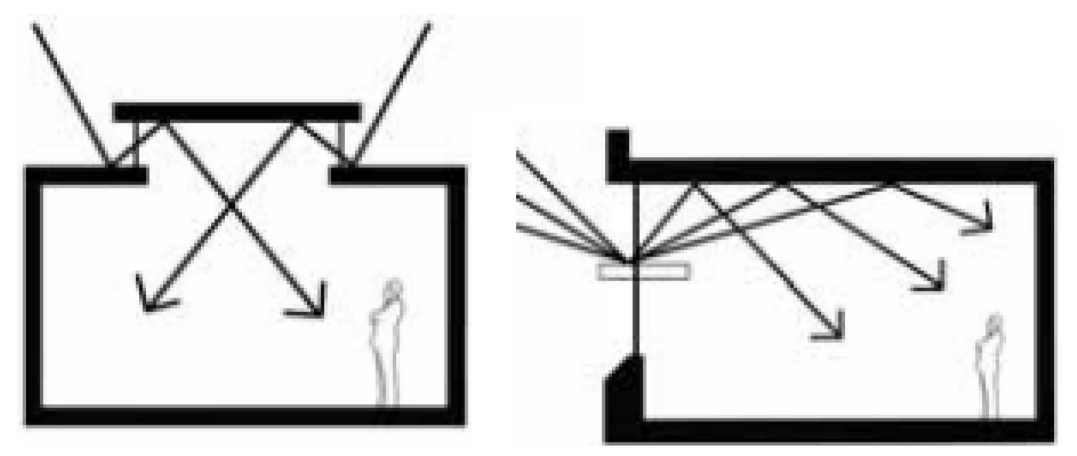

Fig. 2. Daylight solution by north/south facing and light shelf [6] 


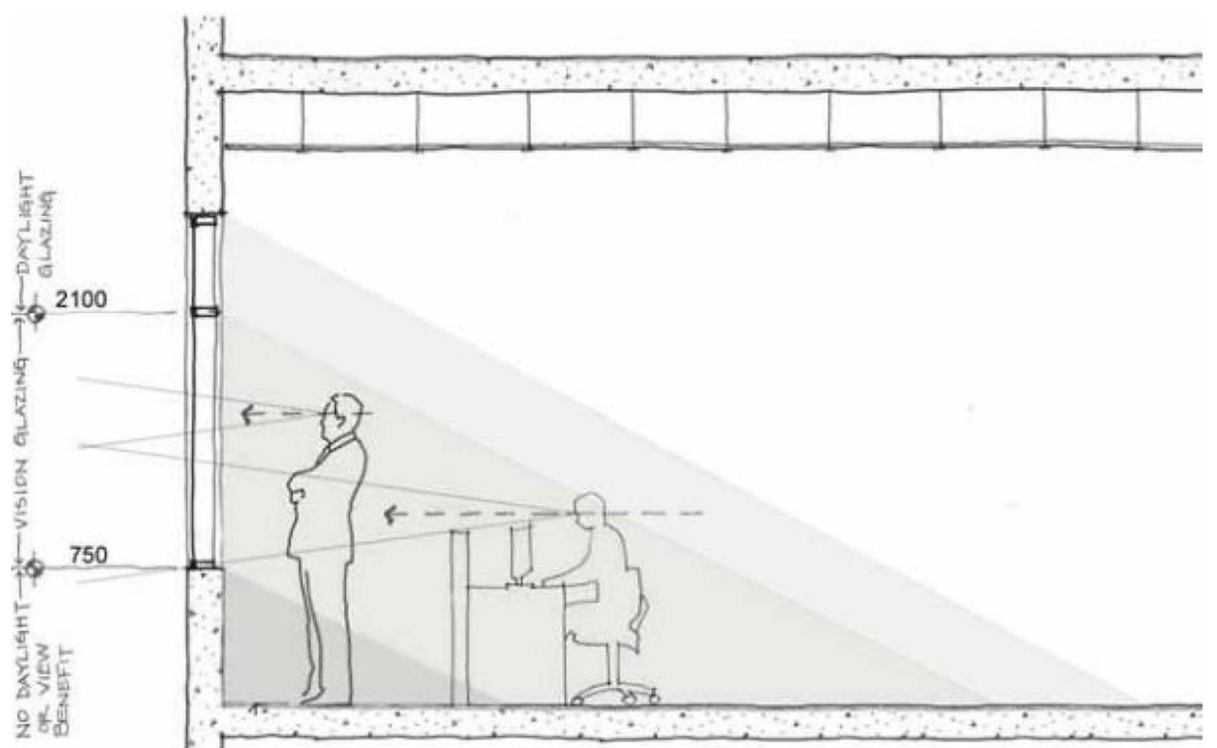

Fig. 3. Effective height of daylight glazing [6]

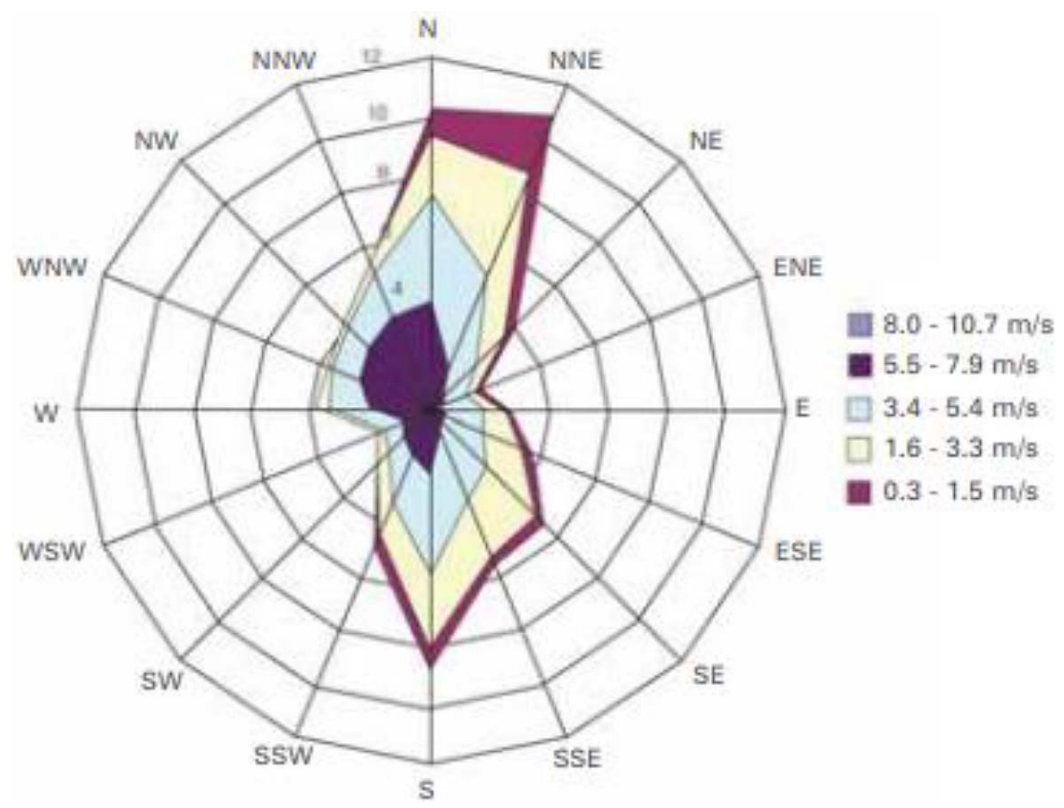

Fig. 4. Singapore wind rose data, Changi Station (1975-2006) [9]

up more than one-third of the world's resources. Also, the construction industry is an essential source of greenhouse gases, causing nearly 30$40 \%$ of global carbon dioxide $\left(\mathrm{CO}_{2}\right)$ emissions in particular. Furthermore, the construction industry is accountable for releasing $30-40 \%$ of global solid wastes. Also, a study pointed out that buildings when designed according to LEED certified or registered, will use less energy, will consume less water, will emit less $\mathrm{CO}_{2}$, and eventually will cost less to be maintained, and occupants will be more satisfied and comfortable. Buildings that usually are designed according to the green specifics have benefits for occupants more than that building are typically designed. Green buildings committed that within 12 years to pay off its cost. And by governmental and commercial planning, buildings can be designed for sustainably less energy and cost to operate and less carbon footprint emission and occupants' satisfaction. The adopted methodology in evaluating building green-designed through energy and water consumption and use, carbon emission, operation and maintenance, waste production, reprocessing and recovering, and occupant satisfaction is mostly effective and can clearly express benefits of system [10]. Human fulfillment level also changes with time and is correlated to various external factors, such as, 


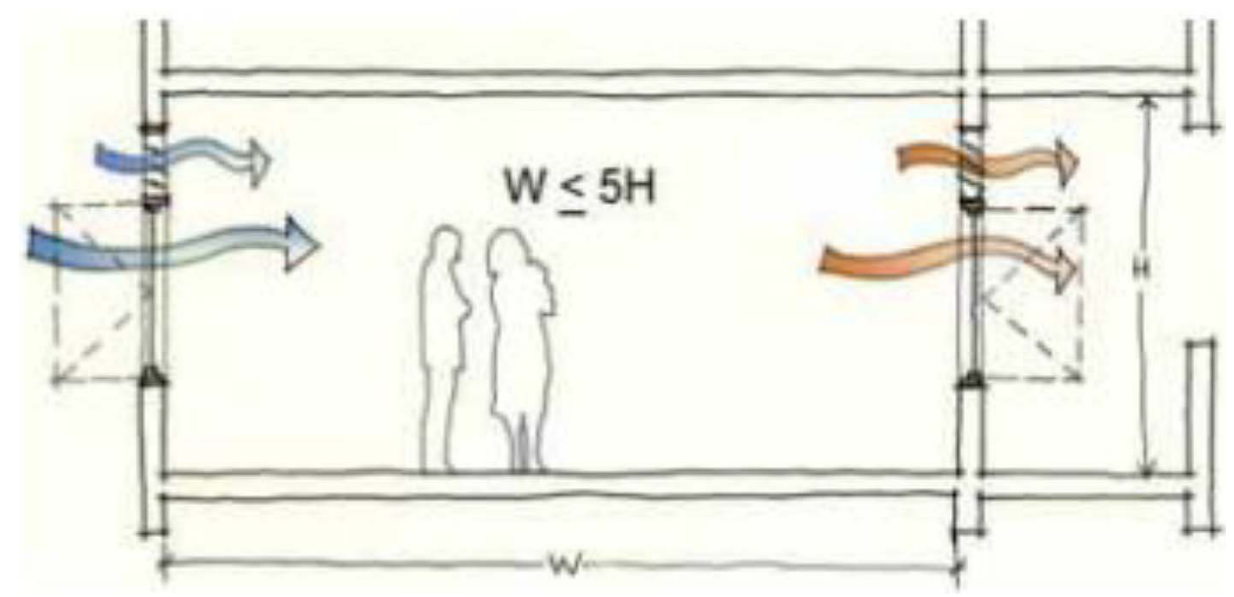

Fig. 5. Design of natural ventilated spaces [6]

costs, ensuring human comfort, safety and enriching the human spirit [11]. Human satisfaction level is also driven by the sustainability goal that in turn dictates the material selection process. Addressing the need of human satisfaction is very important. Another important aspect of material selection is its environmental costs and energy associated at various steps of its manufacturing process. However, to define a green material, numerous factors have to be considered.

Even though the interest in green building is increasing practical knowledge, public awareness is still limited. Thus, there is a need to improve a better understanding of sustainable strategies and practices. As a fact, little research has been made on the awareness level of the public on behalf of the implementation of green buildings. This study aims to evaluate the public's understanding level of the construction industry in Saudi Arabia through the identification factors affecting green building awareness and the evaluation of green building performance in measures. So, in the Green Eco Village, the first stage is the planning and zoning of project area prior to construction. Then fencing of eco systems in the site such as water bodies and plants, and selecting of materials resources within $100 \mathrm{~km}$ radius around the project to reduce the overall carbon emission within the footprint effectively. Specific activities are started in specific zones for construction to control transportation. Construction mud mortar is used in foundations to stabilize and stabilizing blocks in walls, plastering, and for roofing and in mud tiles [12]. Also reinforced block is used to minimize the effect of earthquakes. Calculations show that the brick wall consumes $5.67 \mathrm{MJ} / \mathrm{kg}$, while mud wall consumes $0.55 \mathrm{MJ} / \mathrm{kg}$ for block and plastering. Also the use of assembled arch panel will be less in cost on reinforced concrete and plastering, saves waste in cement and plastering and give more strength. While the use of air gab between tiles and support of roof will work as insulation effectively. In addition to the use of recycled water in construction that will increase sustainability of resources [13].

\section{Green building systems' concepts and measurements}

Four concepts in green construction were often concerned, which are eco-friendly, sustainable, passive, and energy-friendly. The energy-friendly construction stands by the European Union (EU) regulations of the E-standards, which rely on the nature of heating sources and the padding characteristics of a building. Passive construction should meet three criteria: First, heating should not exceed $15 \mathrm{kWh} / \mathrm{m}^{2}$ year. Second, the construction should be air-tight, and third, warmness of the rooms in the summertime should be limited. Finally, the ambiguous concept, eco-friendly, refers to sustainability and recyclability such as using renewable raw materials, frames made out of wood, solar system for heating, photovoltaic cells to provide electricity, and insulating material made of natural fibers. Green building assessment and classification system is built on nine indicators. when the building fulfills 4 out of nine, then green building labels will be awarded [14]. Two of the indicators: electrical and water savings are represented in Table 1.

GBELS has been started since 1999, and any new governmental building enforced to be certified and labeled. The certified green building 
Table 1. Total savings in energy and water on green building [14]

\begin{tabular}{|c|c|c|c|c|c|c|c|c|}
\hline \multirow[b]{2}{*}{ Year } & \multicolumn{4}{|c|}{ Certificated } & \multicolumn{4}{|c|}{ Candidates certificated } \\
\hline & $\begin{array}{l}\text { No. of } \\
\text { projects }\end{array}$ & $\begin{array}{l}\text { Floor area } \\
\qquad\left(\mathrm{m}^{2}\right)\end{array}$ & $\begin{array}{c}\text { Electrical } \\
\text { power saving } \\
(\mathrm{kWh})\end{array}$ & $\begin{array}{c}\text { Water saving } \\
\left(\mathrm{m}^{3} / \mathrm{yr}\right)\end{array}$ & $\begin{array}{l}\text { No. of } \\
\text { projects }\end{array}$ & $\begin{array}{l}\text { Floor area } \\
\qquad\left(\mathrm{m}^{2}\right)\end{array}$ & $\begin{array}{c}\text { Electrical } \\
\text { power saving } \\
(\mathrm{kWh})\end{array}$ & $\begin{array}{l}\text { Water saving } \\
\left(\mathrm{m}^{3} / \mathrm{yr}\right)\end{array}$ \\
\hline 2000 & 1 & 26,750 & 791,795 & 26,362 & 4 & 63,934 & 434,749 & 70,007 \\
\hline 2001 & 2 & 54,875 & 373,174 & 60,088 & 6 & $1,126,173$ & $33,163,923$ & $1,114,654$ \\
\hline 2002 & 5 & 60,770 & 555,667 & 65,860 & 114 & $1,974,146$ & $64,231,261$ & $2,197,663$ \\
\hline 2003 & 5 & 31,248 & 818,340 & 50,547 & 188 & $1,549,722$ & $38,509,405$ & $1,749,723$ \\
\hline 2004 & 18 & 152,618 & $2,938,601$ & 166,254 & 243 & $2,279,567$ & $61,997,286$ & $2,668,922$ \\
\hline 2005 & 42 & 299,441 & $7,505,475$ & 319,066 & 280 & $3,688,532$ & $98,829,337$ & $3,999,192$ \\
\hline 2006 & 42 & 320,078 & $8.404,560$ & 348,493 & 104 & $1,598,187$ & $34,240,640$ & $1,762,179$ \\
\hline Subtotal & 115 & 945,780 & $21,378,585$ & $1,036,670$ & 939 & $12,280,260$ & $331,406,601$ & $13,562,341$ \\
\hline \multirow{4}{*}{ Total } & \multicolumn{6}{|c|}{ Total floor area } & \multicolumn{2}{|c|}{$13,226,039 \mathrm{~m}^{2}$} \\
\hline & \multicolumn{6}{|c|}{ Total electric power saving } & \multicolumn{2}{|c|}{$353,794,186$ kWh } \\
\hline & \multicolumn{6}{|c|}{ Total water saving } & \multicolumn{2}{|c|}{$14,599,010 \mathrm{~m}^{3}$} \\
\hline & \multicolumn{4}{|c|}{ Total saving } & & & \multicolumn{2}{|c|}{ TW\$ 998,777,547 } \\
\hline Remarks & \multicolumn{8}{|c|}{ The calculation depend on the electric power rate $(\mathrm{TW} \$ 2.5 / \mathrm{kWh})$ and water rate $\left(\mathrm{TW} \$ 8 / \mathrm{m}^{3}\right)$} \\
\hline
\end{tabular}

increased from 66 buildings to 773 green building candidates in the year 2005 with an average area of $9,740 \mathrm{~m}^{2}$. Table 1 represents a summary of qualified and candidates projects in GBELS. The table shows that savings in energy reached $352,794.18 \mathrm{KWH}$, while savings in water had been $14,599.01 \mathrm{~m}^{3}$ within seven years. The total savings count for US\$30 Million [14]).

The US Green Building Council's (USGBC) Leadership in Energy and Environmental Design (LEED) Rating System is a nationally accepted third party certification program for green building design, construction, and operation. LEED provides four measures of performance: basic certification, silver, gold, and platinum, based on a set of prerequisites and credits in the five major categories listed above. Each measure represents an incremental step toward integrating the different components of sustainable design, construction, and operation to achieve optimal performance [15]. Then, plans applied to green building construction should focus on reducing energy consumption, increasing water saving and more conserve for sustainable resources, inventing an effective method to recycle waste, and reducing bad effects on health with maintaining well productivity. A well-known topic among the definitions is considering green building the most effective method to take part in environmentally-friendly construction while, at the same time, taking economic and social factors into account of community.
LEED Gold's emphasis on site development, water conservation, energy efficiency, materials selection, and indoor environmental quality yielded broad complete performance, benefits and in most cases served as a valuable performance indicator. LEED Gold buildings are among the best performers from an operation maintenance cost perspectives. Reduced water utilities consumption, energy utilities consumption, general maintenance, grounds maintenance, waste reduction and recycling, and reasonable costs resulted in considerable savings [16]. The objectives of the category that are affected by green buildings are:

- Objectives for environmental sustainability to:

- reduce the use of resources and future replenishment.

- reduce pollution.

- maintain the natural environment and ecosystem diversity.

- Economic sustainability objectives to:

- promote firms to be effective and competitive in market of construction.

- support local economic variety.

- provide job vacancies.

- Objectives for social sustainability to:

- conform to moral standard during the development process.

- provide appropriate services and facilities to serve the development process.

- provide high-quality, livable development standards. 
Also, Building Research Establishment Environmental Assessment Method (BREEAM) is the oldest green building rating system that used heavily in UK \& EU; though approved in other regions. BREEAM Includes both professional credentialing and building certification. More than 425,000 buildings were included in BREEAM certification. System can be used for any type of building or large scale development in any community. While Leadership in Energy and Environmental Design (LEED) is USGBC and local/national GBCs, building rating system and professional credentialing system. System is developed in the US, but used globally, version 4 is the latest version and rolled out in year 2014 [17]. The advantage of Green Building incorporates both the economic or financial benefits and environmental benefits. Green Building has many advantages that represent the economic benefit side such as reduction of the operating cost, growth of productivity of the employees by $25 \%$ , the decrease of energy consumption, and earning higher returns on the investment and building amount. Furthermore, green buildings implementation helps to reduce maintenance costs, as well as costs of design and waste treatment.

\section{Power depletion and exhausted sources}

The advantage of green building integrates both the economic or financial benefits and environmental benefits. Green building has many advantages that represent the economic benefit side such as reduction of the operating cost, improve work environment and productivity, decreasing in energy consumption, and maximizing investment return [18]. The energy used or produced in a usable form, known as embedded (or embedded) energy can be particularly large for building materials. Pollution includes all the emissions of the mining sites and factories used to produce materials, as well as the emissions of use - formaldehyde and emissions from products used to clean and maintain the material - along with the pollution resulting from its final incineration or landfilling [19]. In most countries, buildings are the largest driver for both energy use and $\mathrm{CO}_{2}$ emissions. Europe's buildings use over $40 \%$ the continent's energy and are responsible for $40 \%$ of its carbon emissions. In the US, the corresponding figures are even larger, with buildings accounting for $48 \%$ of total US GHG emissions. Among developing countries, the share of buildings in total energy use and emissions is much lower, with China's buildings, for example, representing a $10 \%$ share of that nation's energy use. By 2030 , Asian countries are expected to contribute by a third of worldwide GHG emissions. Consequently, the challenge to reduce the energy and GHG footprints of new and existing buildings activities is a very serious one. Green sustainable building has many benefits including: lower operating cost, higher return on investment, greater attraction, enhanced marketability (thorough added values), productivity benefits, and reduced liability and risk, healthier place to live and work, commit social responsibility, future proofed assets, and competitive advantages. Based on added building efficiency and modernization, a study conducted in 2009 by Henley University in the UK found that building sale prices could be increased by as much as $35 \%$ when LEED is certified for the building or project footprint, and 31\% if ENERGY STAR is certified. These certified buildings will be compared to the non-certified buildings when controlling for differences in lease contract, age, height, quality, and sub-market. For non-certified buildings, their value was increased by $5 \%$. According to a study sponsored by the Royal Institute of Chartered Surveyors, building owners can expect between $3 \%$ to $6 \%$ increases in rent premiums for certified eco-design (green) buildings over their traditional counterparts of buildings [20].

So, The basic objectives of any building retrofit should include [21]:

- Improve building performance by reducing energy consumption and associated operational expenses.

- Improve building efficiency by reducing water consumption through operations management and fixture choices.

- Improve indoor environmental comfortability and quality for occupants.

- Document and review all improvements.

- Deter construction waste from landfill.

Consumption of non-renewable and nonreplenishable minerals will be detrimental to the environment and will have disastrous effect on humans. In addition to that, energy consumption during and in use of building is vast. In the US, the built environment accounts for $65 \%$ of all energy consumption [22]. A majority of these resources $(60 \%$ according to USGBC) are consumed in the building and construction industry. From this point, building construction accounts 
for $40 \%$ in country, and about $24 \%$ of these global extractions. In the US, with $4 \%$ of world's population, the consumption of resources is at a amazing $25 \%$ of total resources available in the world [23]. In European Union (EU) the corresponding number is $42 \%$ [24]. In addition, carbon dioxide $\left(\mathrm{CO}_{2}\right)$ emissions from the built construction sites accounts for $35-40 \%$ of emissions, both in the US and in the EU [25]. Not only buildings form of a multitude of products, and therefore technical and biological parts, they also have an important and variable impact on water and energy cycles, air quality (indoor and outdoor) through direct and indirect pollution, and fauna and flora, and on social and economic factors. The increased use of resources that causes pollution and $\mathrm{CO}_{2}$ emissions, focus the need to save and save in energy and resources and the start to use renewable resources for sustainable development [26].

Another aspect of minimizing the consumption is either reusing the same material or recycling the material to mold into a different or similar building product. This also ties into the third criteria i.e., meeting a certain level of end-user satisfaction [27]. [28] and [29] pointed that infrastructure and building construction are responsible for the use and consumption of $60 \%$ of natural resources. And in Europe [30] says that the per capita extraction for building are approximately 4.8 tons/year. It is important to minimize the consumption, as while a material is consumed, its chances for future use are diminishing; hence, its potential utility to future generation is lost [31] and specified later [32].

\section{Sustainability of resources and green building themes}

Sustainability is the a continuous operation that aims to fulfill the needs of present community members without compressing the future generations to fulfill their own needs also. So, the economic, environmental, and social aspects are highly interrelated and connected. And many factors related to sustainability determine whether the building is in green direction or not. Such as these factors include: technology, client request, laws, rating systems, codes and standards and specifications, and marketplaces. Whole project is considered to be in the rating systems as single attribute or multi attribute, and earn accreditation or compliant to a point rating system. Different project types could be rated such as the use of grading systems in the schools. While, offices and industrial building are rated according to product certifications, codes, standards, and specifications. The energy saving star rating system that was developed by the environmental protection agency is used for both products, homes, and commercial buildings to rate the energy savings and consumption activities as single attribute. Building is certified as energy star, if the building can collect 75 points through the evaluation conducted by licensed professionals or official organizations [33].

Construction industry started to consider environmental protection during its operations and processes [9]. Also, the environmental impacts and effects on the buildings through their lifecycle begin from preliminary concept and design, construction, and operation, and those were defined as serious problems for the construction industry as those impacts are restrictions on building users during the life cycle and mainly during operation stage. So, in Taiwan, they started to adopt the green building evaluation and labeling systems of used products. Nine labels were developed for assessment and evaluation including: biodiversity in surrounding nature, applicable and successful greenery, soil opportunities, water content, daily possible energy saving, possible carbon dioxide emission reduction, possible waste reduction, indoor environment, available water resources, and sewerage and garbage system improvement and usage. The target of green building evaluation and labeling system is the to build and establish the semi-self social-environmental benefits and socio-economic systems and neglect the view and minimize the need for contractors, clients and designers. The work had focused on the current practice of GBELS, visualizing and scoping using environmental assessment tools and measures, improving the implementation and application of GBELS nationally and internationally in a convenient methodology for future strategy. And the research had focused on measurement and examination methods, affordable implementation cost, existing and new green building indicator system. A survey was conducted on 200 of developers, architectures, contractors, interior designers and consultants. 78 replies were received from the respondents that forms $39 \%$ of the sample. In addition, interviews were conducted with two of each party of the study. $63 \%$ of respondent agreed that $70 \%$ of the fixed and limited design fee was provided by the clients, and $70 \%$ increase of 
construction material cost and $60 \%$ of the economic benefits after the implementation of the GBELS. $70 \%$ of the interviewers see that green building practices and indicators are existing. And $50 \%$ of the respondent see that there is a need for new green building indicators to be adopted and supported in the existing GBELS and that the existing GBELS are not sufficient. Also, $62 \%$ of the respondents agree that clients should support financially extra design fee for green buildings, and the design process must take longer time for green buildings than convenient one and should consider research for future and environmental requirements and compatibility with existing systems and environment into the new technology and materials and methods. Also, the financial support should adopt these new initiations by the governments as come by $67 \%$ of respondents [34].

Also, according to Chinese Architecture and Building Center [35] there are seven indicators and measures for the assessment and promotion of green building through the rating system adopted by the center. These indicators and measures include greenery, soil water content, daily energy saving, carbon dioxide emission reduction, waste reduction, water resources, and sewerage and garbage improvement. it is required to introduce the green building assessment and classification system, and to establish the green building committee to evaluate and to inspire and to grant green building design. And by the government of Taiwan, the green building was promoted and proposed in 2001 requiring that all public buildings required to consider green building design. Biodiversity indicator includes the aquatic ecology such as ecology ponds, pools, and riverbanks which could be various incrusted environmental greeneries of human disruption free. In addition, greenery measure aims to achieve the improved city temperature through the improvement of ecological environment and the fixed carbon dioxide effects. While soil water content indicator include the direct refinement design and the packing refinement design. Daily energy saving indicator evaluates energy usage for building, air conditioning and lighting design which can be proposed through the local architectural design or style. Carbon dioxide reduction indicator assesses the emissions volume through production and transportation of building materials.

The development of the green building program is the result for the worldwide sustainability aims, Because the green building and the sustainability have been used and employed interchangeably worldwide. Even that sustainability and green building are related, but they are not the same. Sustainability helps in taking decisions concerning building materials for continuous generation. Global and climate change is the reason for the transformation to sustainable development employing the green building process. With concentration on the economy efficiency, protection and restoration of environmental and eco systems for the well of the human being and flora and fauna. The consumption of energy is related to the activities of construction sector and building materials technology. Sustainability is increasingly turning to a key thought of building acceptable and experts with the goal of increasing economic and efficient performance, shielding, and returning environmental systems and cultivating human well-being. To reach sustainability, the following gals should met the minimum consumption of material and energy, reusability and recyclability of the material, human fulfillment, and the minimum environmental impacts and embedded energy related to the technical and human satisfaction. The resources used and reuse by a material include all the mechanisms and energy used to abstract, manner, passage, use, and damp/recycle it in a sustainable manner [36].

Many strategies and technical measures could be used to support sustainability and green building construction decisions and practices. Such as these strategies and promotion measures include: the use of ultra-low flush toilets, minimizes impermeable landscaped areas to charge ground water surface and soil water content, conserve all surviving trees, makes wide reuse and the use of recycled and salvaged maintained materials, maximizes daytime exposure through elevations, and uses at least $25 \%$ less energy than the Model National Energy Code for Buildings. Many of the strategy should be used separately or together as design options or ideas to be considered [37]. So, owners, engineers, and professionals should weigh the benefits of the use of these strategies by technical measures in order to achieve the highest sustainability and green standards. And according to [38],first green team should think deep and extensive about the habitats that may be impacted by the facility and by transportation options and scenarios by employing alternate measures and techniques. 
To summarize, green building is the excersise of generating structures and using procedures and systems that are environmentally accountable for reducing bad impacts and maximizing good impacts and resource-well-organized through a building life-cycle by setting design, construction, operation, maintenance, restoration, and deconstruction (optimizing of construction processes, practices, and cost on short and long time scales. This definition has evolved over the years and life cycle of projects and buildings. Green buildings is an ever developing, dynamic term that goes in continuous operation and strategy. Green building is the position of our efforts in achieving sustainability in building performs through employing well selected materials and technology. According to [39] and [40] various phases of material are presented, which are the base of assessment. "greenness" of a material is assessed on four separate levels:

- Raw-Material Phase (resource restraint, resource abstraction, transference) to be sustainable through mining and for future needs.

- Manufacturing Level (waste decrease, pollution stoppage, recycled matter, embedded energy reduction, use of natural materials) to be sustainable in waste production and transportation.

- Operational level (decrease in construction waste, energy effectiveness, longer life/ durability, occupant health, water action/preservation, use of non-toxic or less toxic materials, renewable energy systems) to be sustainable in erection in minimum waste production and durability to have less maintenance and maximizing the environmental benefits.

- Disposal alternate evaluation in cost against reusability, recyclability, and/or biodegradability.

\section{CONCLUSION}

From the review of articles and literatures in green building, it is concluded that green building standards are available for all type of buildings on a global basis and the standards are well developed and continuously being updated in developed countries. In addition to the green building evaluation and labeling systems that are established worldwide in developed countries and includes a special and experienced institutions such as US Green Building Council's (USGBC) Leadership in Energy and Environmental Design (LEED) Rating System, and Building Research Establishment Environmental Assessment Method (BREEAM) are innovations for green standards and practice and evaluation used worldwide.

The standards cover all phases of a building's life cycle from design to demolition. Considered sustainability performance guarantees the simple work in design, review, construction, maintenance, and operation when based on green building design. Also, existing building can be successfully upgraded and updated through renovation considering sustainable standards that are developed for existing building. And green building has less consumption in energy, water, $\mathrm{CO}_{2}$ emissions, and waste, and less cost for maintenance. Also, buildings when design to green standards will payback its cost in short time compared to other buildings designed and constructed arbitrary. Building through construction and operation are related to $40 \%$ of energy consumption and $\mathrm{Co}_{2}$ emission. So, the use of natural materials from local materials will decrease $\mathrm{CO}_{2}$ emissions and sustain materials resources from depletion and decrease the cost of construction. Most of companies in developing countries have no data centers or records for new building construction or renovation of existing buildings according to green building requirements and specifications. Companies owners (contractors, design firms, and developers), clients, consultants, and occupants and buyers see that green building impose an extra capital cost for construction that can't be afforded by any part of process, especially with the low income and absence of specifications that obligate the design and construction to be compatible with green building requirements. It is essential to start establishing of councils that will be responsible for setting specifications and practices by governmental (public sector) and nongovernmental (private sector) in a partnership for developing green building features and start keeping records and prove that green building has efficient financial performance and benefits considering the level of environmental sustainability and green building innovations.

\section{Acknowledgments}

The author would like to direct his great thanks to the colleagues in the department of civil engineering and faculty of engineering and the presidency administration and the family and sons. 


\section{REFERENCES}

1. Al-Ali Z.S. Analysis of project costs for green buildings in the UAE: A case study, The British University of Dubai, Faculty of Business. 2014.

2. Abuamer E., Boolaky M. Consumer behavior towards green building: a study in Abu Dhabi. International Journal of Business Administration. 2015;6(3):72-83.

3. Jordan Green Building Council. Your guide to green building in Jordan, green building informative booklet. 2017. https://rise.esmap.org/data/files/library/ jordan/Energy\%20Efficiency/Jordan_Guide $\% 20$ to $\% 20$ green $\% 20$ building $\% 20 \mathrm{in} \% 20 \mathrm{Jordan}$.pdf

4. Smith T. Green building project example. 2010. http://www.deland.org/Pages/ DeLandFL_Building/GreenPresentation.pdf

5. Aghili N., Mohammed A.H., Shean-Ting L. A Review on green building index: management criteria, Department of Real Estate, University Teknologi Malaysia, Johor, Malaysia. 2016.

6. Building Construction Authority (BCA), Green Building Platinum Series. Building Planning and Massing. 2010.

7. Aliagha G.U., Hashim M., Sanni A.O., Ali K.N. Review of green building demand factors for Malaysia, Journal of Energy Technologies and Policy. 2013;3(11).

8. Azizi M.S., Fassman E., Wilkinson S. Risks associated in implementation of green buildings. Auckland, New Zealand: Department of Civil Environmental Engineering. 2010.

9. Tam V.W.Y. The effectiveness of the green building evaluation and labeling system. Architectural Science Review. 2007.

10. Bailey L. What you should know before calling your project "LEED certifiable". New leaf sustainability consulting. 2014.

11. Day C. Places of the soul. Aquarian Press, San Francisco, CA. 1990.

12. Begum R.A., Pereira J.J. GHG emissions and energy efficiency potential in the building sector of Malaysia, Australian Journal of Basic and Applied Sciences. 2010;4(10).

13. Green Building Technology. 2013. Govardhan Eco Village. http://ecovillage.org.in/wp-content/Downloads/Green-Building-Technology.pdf

14. Lin H.T., Sun C.Y., Lin Y.J., Chen C.J., Shih J.Y. Good to be Green: Green Building Promotion Policy in Taiwan. Taipei, Taiwan, Ministry of Interior, Architecture and Building Research Institute. 2006.

15. General Services Administration (GSA) Public Building Services 2011. Green Building Performance. https://www.gsa.gov/graphics/pbs/Green Building_Performance.pdf
16. Cam C.N., Ong B.L. Building environmental assessment tools and the multidimensional pathways towards sustainable architecture. In Proceedings of the 2005 world sustainable building conference (SB05Tokyo). Tokyo, Japan 2005, 27-29.

17. Doan D.T., Ghaffarianhoseini A., Naismith N., Zhang T., Ghaffarianhoseini A., Tookey J. A critical comparison of green building rating systems. Building and Environment. 2017;123:243-260.

18. Kim, J.-L., Greene M., Kim S. Economic impact of new green building code on residential project development from energy consumption. Journal of Green Building. 2014;9:105-123.

19. Milani B. Building materials in a green economy: Community-based strategies for dematerialization. PhD Dissertation, University of Toronto, Canada 2005.

20. DOE U. Building energy data book. Energy Efficiency \& Renewable Energy Department. The United States Energy Information Administration (EIA). 2011;1-271.

21. Go Green. Sustainable Building. 2012. https:// www.itu.int/dms_pub/itu-t/oth/4B/04/T4B 0400000B0012PDFE.pdf

22. United States Green Building Council (USGBC). New Construction and Major Renovation Reference Guide. USGBC, Washington D.C. 2009.

23. Teller M., Bergman J. Sustainable design for structural engineers. STRUCTURE magazine, A joint publication of NCSEA/CASE/SEI, December 2010.

24. Nelson A.I. The greening of the U.S. investment real estate, markets fundamentals, prospects and opportunities RREEF research.

25. Kearney D. Energy information administration outlook through 2035 from the annual energy outlook 2010. Energy Information Administration, U.S. Department of Energy, Surface Transportation Board. 2010.

26. El Montasser G., Ajmi A.N., Nguyen D.K.. Carbon emissions - income relationships with structural breaks: the case of the Middle Eastern and North African countries. Environmental Science and Pollution Research. 2018;25(3):2869-2878.

27. Pearce A., Makarand H., Vanegas J. A decision support system for construction materials selection using sustainability as a criterion. In: Proceedings of the 28th Annual Conference, National Conference of States on Building Codes and Standards. Albuquerque, New Mexico 1995, 1-4.

28. Bribian I.Z., Capilla A.V., Uson A.A. Life cycle assessment of building materials: comparative analysis of energy and environmental impacts and evaluation of the eco-efficiency improvement potential. Build Environ. 2011;46:1133-1140.

29. Mining, Minerals and Sustainable Development (MMSD). Breaking new ground: The report of the 
mining, minerals, and sustainable development project." mining, minerals, and sustainable development. (MMSD), Earth scan for International Institute for Environment Development (IIED) and World Business Council for Sustainable Development (WBCSD). 2002.

30. ECD. Greening the NEWS Report-A Guide to sustainable Engineering Specification, London: ECD Energy and Environment Ltd., Windsor, UK: Barbour Index Plc. 2001.

31. Heerwagen J.H. Green Buildings, Organizational Success, and Occupant Productivity. Building Research and Information. 2000;28(5):353-367.

32. DTI. The Digest of United Kingdom Energy Statistics, Department of Trade and Industry, Crown Copyright, UK. 2005.

33. Arzeta K., Mlis, A. Green building standards, sustainable design overview for information professionals. 2015. https:/www.sla.org/wp-content/ uploads/2015/06/1486_HotTopicsin ArchitectBldgDsgnArzeta.pdf
34. Tse Y.C.R. The Implementation of EMS in construction firms. case study in Hong Kong. Journal of Environmental Assessment Policy and Management. 2001;3:177-194.

35. Chinese Architecture and Building Center. The achievement and benefit of green building evaluation and labeling system. City Publisher. 2007.

36. Sinha A., Gupta R., Kuntar A. Sustainable development and green buildings. 2012.

37. Woolliams J. Planning, design and construction strategies for green buildings. eco-city planning company. 2001. https:/www.greenbiz.com/sites/ default/files/document/O16F22028.pdf

38. Fowler K.M., Rauch E.M. Sustainable Building Rating Systems Summary (No. PNNL-15858). Pacific Northwest National Lab. (PNNL), Richland, WA (United States). 2006.

39. Fellows R.F., Liu A.M. Research Methods for Construction. John Wiley \& Sons. 2009.

40. Spiegel R., Meadows D. Green Building Materials - A guide to product selection and specification. $2^{\text {nd }}$ edition. John Wiley and Sons, Virginia, USA. 2006 